\title{
Conclusion - A Comparative Assessment of the Findings
}

Basic information from the field visits (see Table 4) indicates that the four countries Botswana, Ghana, Uganda and Zambia - have been engaged in various public sector reform projects, and have instituted employment contracts (i.e. contract of service) and contract-like arrangements which are associated with the new management of senior public service officers including the permanent secretaries. The permanent secretary in each country is still effectively the chief executive of the ministry/department or administrative region. This senior public service officer is called a chief director (formerly principal secretary) in Ghana, whereas the other three countries have retained the name permanent secretary. The data show (Table 4) that Uganda had 17 (out of an expected 21), Zambia 42, Ghana 37 and Botswana 29 permanent secretaries/chief directors respectively. Of these, all 17 permanent secretaries are on employment contract in Uganda; all 42 in Zambia are also on employment contracts; and all 29 in Botswana have signed a performance agreement. Ghana has a mixed basket, with only 8 of the 37 chief directors on employment contract of three to four years and 22 on open tenure (or permanent and pensionable) while 3 are on an employment contract which is called 'limited engagement'. A 'limited engagement' contract is normally a short-term contract of between one and three years' duration. It tends to be given to chief directors who have just retired, but whose services are still needed by the state. All the chief directors in Ghana also sign a performance agreement. The age of retirement in Botswana, Ghana and Uganda is 60 years, and it is pegged at 55 for Zambia.

None of the permanent secretaries in the four countries has delegated authority for the human resource function, especially in terms of hire and fire. In each case the Public Service Commission (PSC) still retains these functions and is also the key agency which makes recommendations for promotions and reward or sanction of public employees. In Zambia, however, the Cabinet Handbook of 2002 notes that the permanent secretary can appoint one cabinet liaison officer, whose duty it is to coordinate all Cabinet business within the ministry and retain day-to-day contact with the Policy and Co-ordination Division at the Office of the President. An important novelty that was discovered was in Botswana, where the government has established, at the Office of the President, a Directorate of Public Service Management (DPSM) which handles most of the human resource functions of the state. In an interview with Pearl Matome, Deputy Director at the DPSM, the Botswana Public Service 
Commission has only been used as an appellate body. This means that aggrieved public employees have the right to refer their problems to the PSC for redress.

A simple gender analysis of serving permanent secretaries/chief directors reveals that there are 12 male and 5 female permanent secretaries in Uganda; 37 male and 5 female permanent secretaries in Zambia, and 31 male and 6 female chief directors in Ghana. This picture is nothing out of the ordinary, it is only slightly better than the patriarchy at the level of head of state in the continent, where there is only one female head of state (who is located in Liberia).

An important characteristic of African public administration (in the case study countries) is the size of government, and this is one area that is dynamic and is subject to regular review, as governments reform their bureaucracies in response to the changing constitutional requirements and the international environment. At the time of the fieldwork in July 2008 Uganda had 21 government ministries, Zambia had 22, Botswana had 15 and Ghana had 27. In each of the four countries, there were three tiers of government - central, regional and local government. In Zambia and Ghana, the regional level of administration is headed by a permanent secretary or chief director, and this in a way explains the high number of permanent secretaries and chief directors recorded in those countries. 


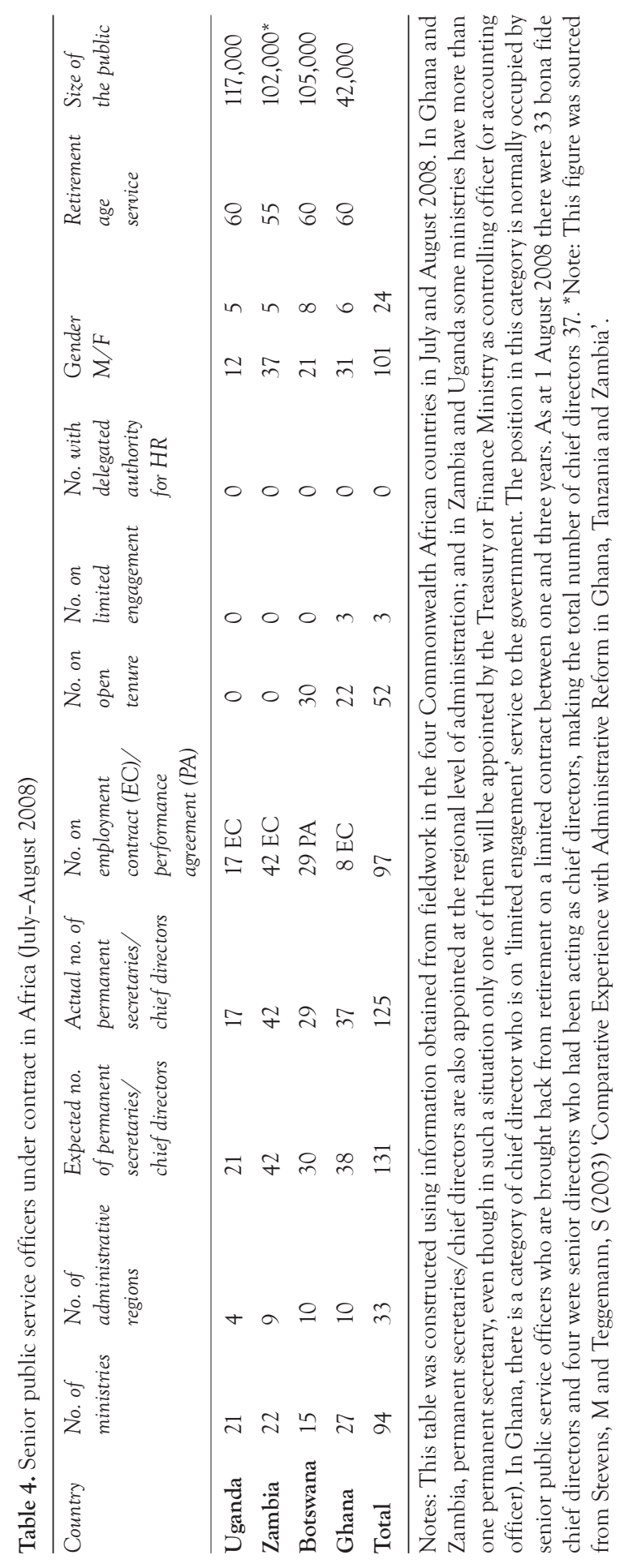




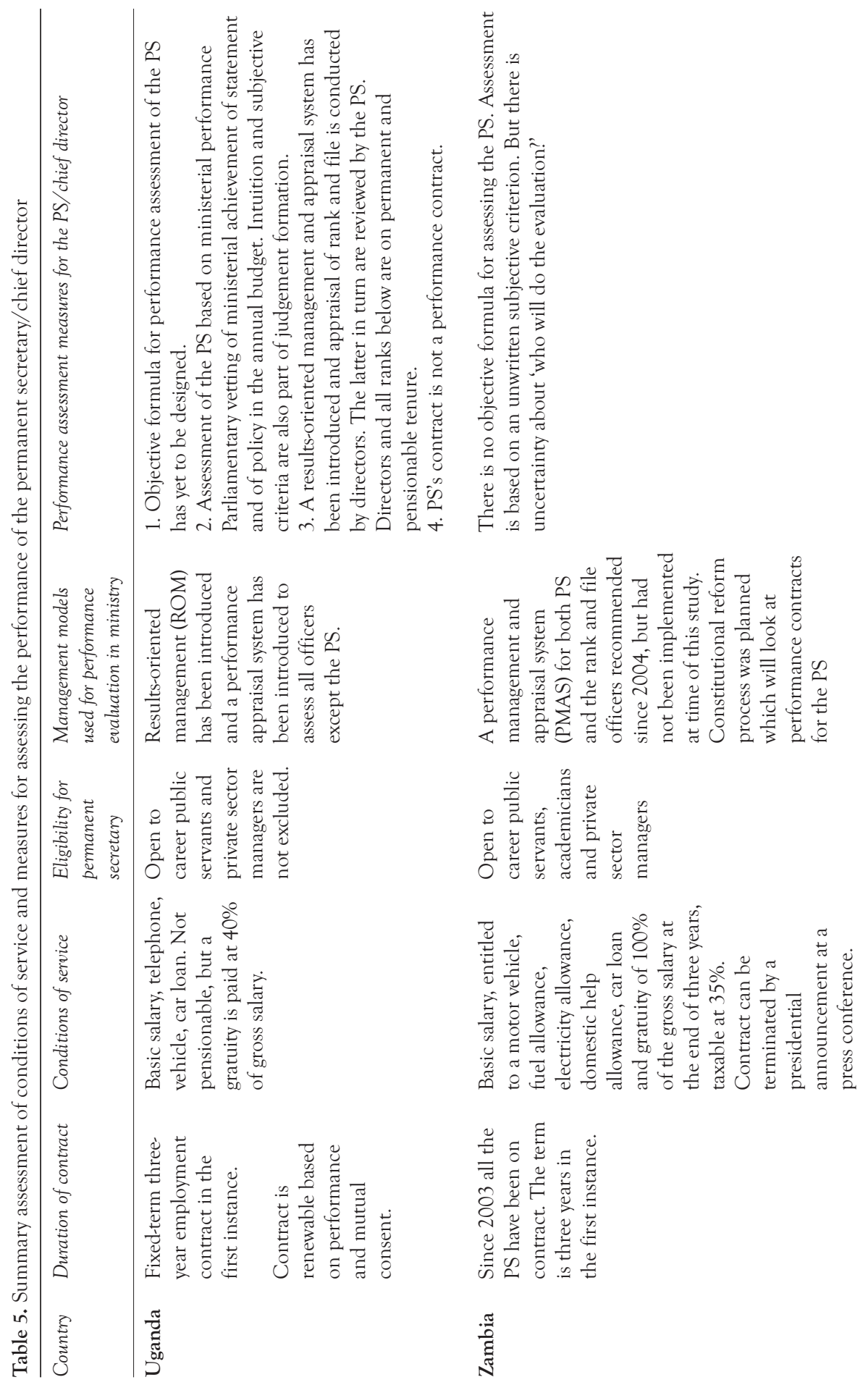




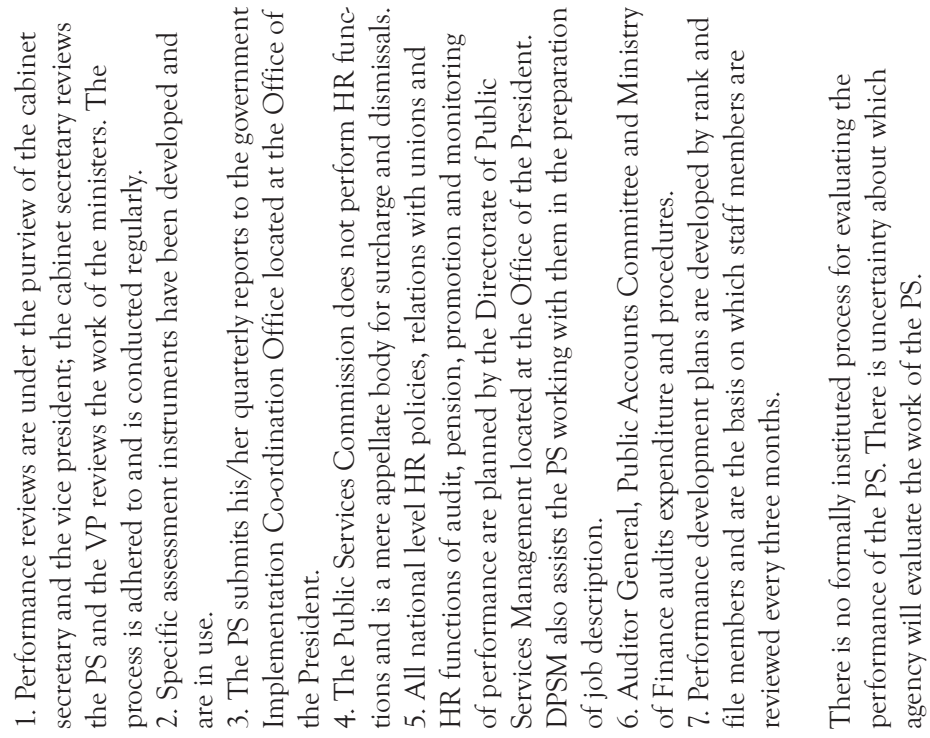

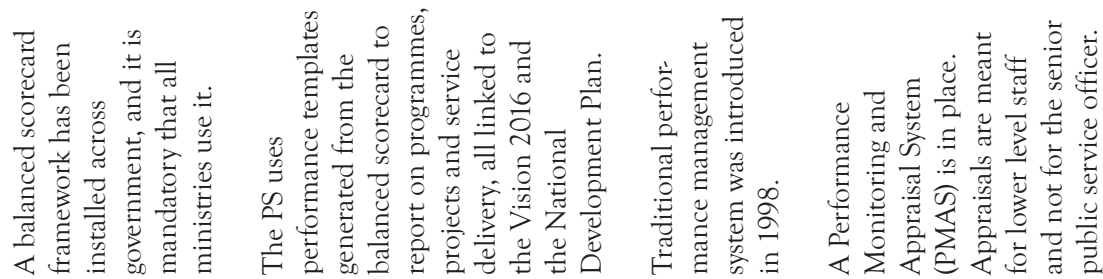

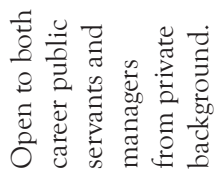

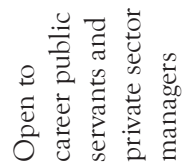

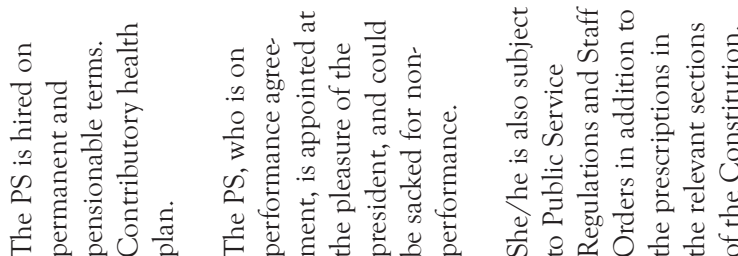

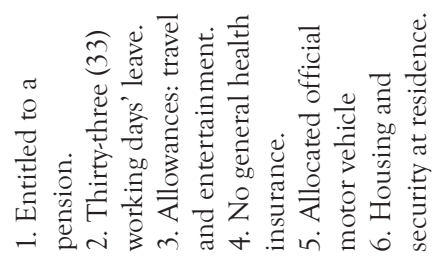

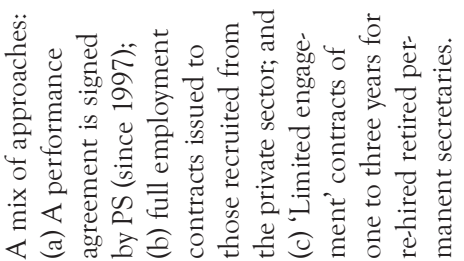

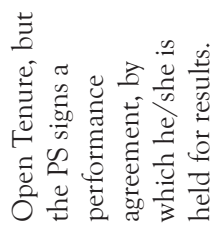

䒕

䒕 


\section{Management approaches adopted in the reform}

Table 6. Characteristics of the contract systems reform in four African countries

\begin{tabular}{|c|c|c|c|c|}
\hline Country & $\begin{array}{l}\text { National economic } \\
\text { management framework }\end{array}$ & System of governance & $\begin{array}{l}\text { Appointing authority } \\
\text { of PS }\end{array}$ & $\begin{array}{l}\text { Signatories to the } \\
\text { contract }\end{array}$ \\
\hline Ghana & $\begin{array}{l}\text { Ghana Poverty } \\
\text { Reduction Strategy } \\
\text { (GPRS) II, which is } \\
\text { donor supported }\end{array}$ & $\begin{array}{l}\text { Fused Executive } \\
\text { Presidency \& Head } \\
\text { of State }\end{array}$ & $\begin{array}{l}\text { President of the } \\
\text { Republic acting on } \\
\text { advice of Public } \\
\text { Service Commission } \\
\text { and Civil Service } \\
\text { Council }\end{array}$ & $\begin{array}{l}\text { Head of the Civil } \\
\text { Service, and the } \\
\text { chief director }\end{array}$ \\
\hline Botswana & $\begin{array}{l}\text { Vision } 2016 \text { and } \\
\text { National Develop- } \\
\text { ment Plan, which are } \\
\text { locally supported }\end{array}$ & $\begin{array}{l}\text { Fused Executive } \\
\text { Presidency \& Head } \\
\text { of State }\end{array}$ & $\begin{array}{l}\text { President of the } \\
\text { Republic }\end{array}$ & $\begin{array}{l}\text { Cabinet secretary/ } \\
\text { public service } \\
\text { president, and the } \\
\text { permanent secretary }\end{array}$ \\
\hline Uganda & $\begin{array}{l}\text { Poverty Eradication } \\
\text { Action Plan (PEAP), } \\
\text { which is donor } \\
\text { supported }\end{array}$ & $\begin{array}{l}\text { Fused Executive } \\
\text { Presidency \& Head } \\
\text { of State }\end{array}$ & $\begin{array}{l}\text { President of the } \\
\text { Republic acting on } \\
\text { advice of the Public } \\
\text { Service Commission, } \\
\text { and cabinet secretary }\end{array}$ & $\begin{array}{l}\text { Cabinet secretary/ } \\
\text { Head of Public } \\
\text { Service, and the } \\
\text { permanent secretary }\end{array}$ \\
\hline Zambia & $\begin{array}{l}\text { Poverty Reduction } \\
\text { Strategy Papers }\end{array}$ & $\begin{array}{l}\text { Fused Executive } \\
\text { Presidency \& Head } \\
\text { of State }\end{array}$ & $\begin{array}{l}\text { President of the } \\
\text { Republic acting } \\
\text { through the cabinet } \\
\text { secretary }\end{array}$ & $\begin{array}{l}\text { Cabinet secretary/ } \\
\text { Head of Public } \\
\text { Service, and the } \\
\text { permanent secretary }\end{array}$ \\
\hline
\end{tabular}

Source: Compiled from field notes from Ghana, Botswana, Uganda and Zambia, July-August 2008.

A broader look at the management of the political economy in each country underscores the nature of the national governance environment in which the contract systems for permanent secretaries were established. Every country was pursuing an economic reform programme which required new management capacities and new ways of bureaucratic management. From Table 6 we see that Ghana was implementing a Poverty Reduction Strategy II, a successor programme to the Heavily Indebted Poor Country initiative (HIPC) of the Bretton Woods Institutions which was signed in 2001. Similar HIPC continuation programmes were also being implemented in Uganda and Zambia in the form of Poverty Eradication Action Plan and Poverty Reduction Strategy Paper respectively.

\section{How is performance measured and rewarded under the contract system?}

Different management models for achieving efficiencies were at different stages of implementation in each country (as shown on Table 5). Uganda had begun to institutionalise a results-oriented management (ROM) across government, a model by which public management for results will be organised and conducted. In Zambia the thought of introducing a Performance Management and Appraisal System was still 
at the embryonic stage, whereas Ghana had instituted a similar system since 1998. Ghana, Uganda and Zambia had not devised measurement systems for assessing the performance of the permanent secretary and chief director, and this constituted a serious flaw in the performance systems that they were seeking to install. However, the Head of the Public Service in each country was aware of this shortfall and they were at various stages of finding solutions to the performance contract question. Indeed, all the permanent secretaries who were interviewed alluded to the need to turn their employment contracts into performance contracts, with effective measures to evaluate their performance.

Botswana had made the greatest advancement in this area of performance management and measurement. The country had installed a PMAS in the latter part of the 2001 and introduced a balanced scorecard management model by 2004. The balanced scorecard was implemented across government and it had separate templates which allowed each permanent secretary to report on public management measures and project updates in a more business-like way than had been tried before in that economy. Reviews of the work of the permanent secretary and rankand-file civil servants were reported to be carried out on a quarterly basis, with fail. Botswana was therefore seen as proffering a model that was worthy of emulation by the other countries.

\section{The scope of and potential for expression of leadership by the permanent secretary/chief director}

From the interviews with permanent secretaries and chief directors in the four countries, two main issues emerged as important factors which impinge on the expression of leadership by these senior public service officers. These are the availability of revenues and the remuneration of the permanent secretary in relation to heads of department of statutory bodies to whom, administratively, they are senior. The inadequacy of budgetary resources was important to the permanent secretaries in Ghana, Uganda, and Zambia. This issue was not particularly acute in Botswana, where a mixture of good fortune in terms of a small population of the country (approximately 2 million) and diamond reserves have ensured that the public sector has remained financially stable. On the other hand, the issue of subordinates earning more that the permanent secretary, who is the administrative head of the ministry and to whom the heads of statutory corporations report, was noted as a concern in Zambia. To the relevant Zambian senior public service officers, this inequity gets in the way of the exercise of leadership over statutory corporations which are under their purview.

\section{How the contract system impinges on the independence of the permanent secretary/chief director}

The independence of permanent secretaries and chief directors in the four countries seemed to be helped tremendously by the creation of written rules and constitution 
concerning the roles of the permanent secretary, deputy minister and minister. The Cabinet Handbook 2002 of Zambia, the Civil Service Act, Law 327 of 1993 and the constitutions of all the four countries have determined the precise roles of public officials. The instructions issued to permanent secretaries and chief directors by the ministry responsible for finance on their appointment as controlling officers in terms of financial management of their ministries are also another source of good practice for the prevention of confusion in financial management. Permanent secretaries and chief directors are occasionally called upon to answer queries raised by the Public Accounts Committee of Parliament in each country and that has acted as a source of encouragement for the senior public service officers to manage their ministries with integrity.

\section{How is conflict mediated in the contract system?}

Two likely sources of conflict were isolated in the governance structures of the public services in the four African countries. These are the personal/political interests of ministers which are likely to play out in spending of public resources and meeting of ministers with heads of departments without the permanent secretary being present. In the first case, the financial instructions from the ministry responsible for finance to permanent secretaries make it expressly clear that where a minister gives instruction for the permanent secretary to spend public funds which is likely to compromise the integrity of the latter, the permanent secretary should require those instructions to be in written form. Similarly, if the minister is adamant and insists on the expenditure of these funds against the rules, the permanent secretary may submit the written instructions to the minister of finance and the Auditor-General. This practice is common to all the four countries. However, in Zambia this institution is further emphasised in the Cabinet Handbook of 2002.

\section{Value for money of the contract systems}

With regard to the question of whether the contract systems pertaining to the employment of permanent secretaries were delivering value for money, the public officials interviewed in Ghana, Uganda and Zambia felt that even though the present management systems are an improvement on the previous practice, value for money was not being fully derived for the country. This is because the performance management models have only been partially implemented and performance agreements and contracts of employment have not been buttressed by the necessary measurement instruments to enable full accountability. The officers in Botswana were confident that their balanced scorecard system was proving successful because the system is practised across government and permanent secretaries and ministers of government were adhering to the reporting practices, while the cabinet secretary and Vice President of the country were also ensuring that the performance reports were reviewed on a quarterly basis without fail. 


\section{Conclusions and lessons learned}

This study set out to examine the contract systems pertaining to the employment of permanent secretaries and chief directors in Botswana, Ghana, Uganda and Zambia. This was necessary because these countries had embarked on the reform of their public services since the latter part of the 1990s with a view to infusing public administration systems with private sector practices, which have been deemed to be proficient in turning around malfunctioning public services. This new way of reforming the public service had come about a result of the sea change in the ideology of administration called the 'new public management'.

Qualitative research methods were used including literature review and primary research which involved elite interviews and assessment of policy documents and evaluation reports commissioned by the governments of those countries. Field visits afforded a unique opportunity for direct observation of the work of permanent secretaries and chief directors. These methods were appropriate to the kind of audience encountered who were mostly from the highest level at the centre of government. This claim is significant because an online survey which had been designed to assist in a simultaneous rapid assessment of permanent secretaries in the Caribbean had to be abandoned in the African study for reasons of non-patronage by the target group.

The research revealed that a broad range of new management practices for managing public services and senior public service officers had been adopted in Botswana, Ghana, Uganda and Zambia. All four countries had instituted contracts of employment and contract-like arrangements in the form of performance agreements, contracts of employment and the retention of a good mix of the old permanent and pensionable modes of employment, which were signed by the permanent secretaries and chief directors with their governments. In Botswana, Uganda and Zambia the superior or employing authority (government) were normally represented by the cabinet secretary. The experiences of these countries do not necessarily represent a wholesale borrowing of the New Zealand model, but certainly the ideas about improving public service delivery systems using contractual re-engineering processes were borrowed and translated. However, even though each country's experience is unique, reflecting the alignment of power and forces of interest, there were also important commonalities to be drawn.

Contract entitlements generally included gratuities and access to official vehicles in all countries. In the contract-like arrangements under which permanent secretaries and chief directors operated, state pension schemes had been retained in Ghana and Botswana, while gratuities of 40 per cent and 100 per cent of gross salary were paid to permanent secretaries in Uganda and Zambia respectively. The basic pay of the Zambian permanent secretary was considered to be very low by the Independent Management Consulting Company in 2004. The same agency also noted that the gratuity of 100 per cent that is taxed at 35 per cent on collection at the end of the 
three-year contract does not necessarily show that the system is generous. It argued that bringing the pay of the permanent secretary to market levels might actually be a better option. In Ghana, Uganda and Zambia where contracts of employment have been issued to permanent secretaries and chief directors, the norm for length of a term tended to be three years.

The most important finding of the study is that to benefit from performance improvements associated with these contractual arrangements, countries must fully implement performance contracts or back up their performance agreements with performance management and performance measurement instruments which can be evaluated at regular intervals, and the performance information fed back to improve management. In this regard, 'Performance and Co-ordination Units' will be needed at the Office of Cabinet or Office of the Head of the Civil Service (as appropriate), with local units at each ministry to ensure compliance and policy co-ordination.

These arrangements will be congruent with the institutions in Botswana where a balanced scorecard system has been installed and is seemingly producing value for money for the government and people of the country. One issue that is still not established, with available information, is whether Botswana's success has anything to do with the small size of its population of 2 million and a public service of about 15,000 , while the other countries have large populations of over 20 million each and larger public services. The issue of bringing ministers and permanent secretaries to a certain level of knowledge and understanding of public policy and public service delivery, and to press home a common view that the two succeed or fail together might also be a key lesson to learn from Botswana by the other countries.

This study, however, cannot make over-reaching conclusions about the detailed workings of the public service systems in those countries as it concentrated on institutional aspects of implementation of the chosen models by each country, and the length of time spent in each country did not permit an ethnographic type study. 